\title{
Telomere length and oxidative stress variations in a murine model of Alzheimer's
}

\section{disease progression}

Katia Martínez-González ${ }^{1,2}$, Azul Islas-Hernández ${ }^{1,2}$, José Darío Martínez-Ezquerro ${ }^{3}$,

Federico Bermúdez-Rattoni ${ }^{4}$, Paola Garcia-delaTorre ${ }^{1^{*}}$

${ }^{1}$ Unidad de Investigación Médica en Enfermedades Neurológicas, Hospital de

Especialidades, Centro Médico Nacional Siglo XXI, Instituto Mexicano del Seguro Social,

México

${ }^{2}$ Posgrado en Ciencias Biológicas, Universidad Nacional Autónoma de México (Unidad de

Posgrado, Edificio A $1^{\circ}$ piso, Circuito de posgrados, CU, Coyoacán, CDMX 04510,

México)

${ }^{3}$ Unidad de Investigación Epidemiológica y en Servicios de Salud, Área de

Envejecimiento, Centro Médico Nacional Siglo XXI, Instituto Mexicano del Seguro Social,

México

${ }^{4}$ División de Neurociencias, Instituto de Fisiología Celular, Universidad Nacional

Autónoma de México, AP 70-253, CDMX 04510, Mexico

*Corresponding author: Paola Garcia-delaTorre

Cuauhtémoc 330, Col. Doctores, Delegación Cuauhtémoc, Ciudad de México, México; pgarciatorre@gmail.com

Keywords: lifespan, neurogenesis, hippocampus, blood cells, biological clock 


\begin{abstract}
Alzheimer's Disease (AD) is the most common cause of dementia and aging is its major risk factor. Changes in telomere length have been associated with aging and some degenerative diseases. Our aim was to explore some of the molecular changes caused by the progression of $\mathrm{AD}$ in a transgenic murine model (3xTg-AD; B6; 129-Psen1 $<$ tm1Mpm $>$ Tg (APPSwe, tauP301L) 1Lfa). Telomere length was assessed by qPCR in both brain tissue and peripheral blood cells and compared between three age groups: 5, 9, and 13 months. In addition, a possible effect of oxidative stress on telomere length and AD progression was explored. Shorter telomeres were found in blood cells of older transgenic mice compared to younger and wild type mice but no changes in telomere length in the hippocampus. An increase in oxidative stress with age was found for all strains but no correlation was found between oxidative stress and shorter telomere length for transgenic mice. Telomere length and oxidative stress are affected by AD progression in the $3 \times \mathrm{Tg}-\mathrm{AD}$ murine model. Changes in blood cells are more noticeable than changes in brain tissue, suggesting that systemic changes can be detected early in the disease in this murine model.
\end{abstract}




\section{Introduction}

Alzheimer's disease (AD), the most common cause of dementia, is defined by progressive and irreversible neurodegeneration of the central nervous system that eventually leads to the gradual decline of cognitive function (Czech et al., 2000; Oddo et al., 2003). The main feature of this disease is the deposition of amyloid- $\beta(\mathrm{A} \beta)$ protein in the extracellular space of the cerebral cortex and the walls of cerebral blood vessels. It has traditionally been thought that the $A \beta$ deposited in the brain originates from the brain itself. However, it has recently been speculated that it may also come from $\mathrm{A} \beta$ at the periphery circulating in the blood. It is known that peripheral exposure to $A \beta$-rich brain extracts can also induce cerebral $A \beta$ deposits in transgenic mice (Meyer-Luehmann et al., 2006). In this regard, insoluble $A \beta$ oligomers have been experimentally shown to cause memory dysfunction, inhibit LTP, and prolong LTD (Ding et al., 2019).

In addition to these neuronal lesions, some biomarkers of genomic instability have been found in patients with $\mathrm{AD}$, including micronuclei (markers of loss and breakage of chromosomes), aneuploidies of chromosome 21, shortening of telomeres in lymphocytes and fibroblasts (Thomas et al., 2008), and increased oxidative stress markers (Butterfield \& Sultana, 2011).

Telomeres are essential non-coding deoxyribonucleic acid (DNA)-protein complexes that cap the ends of the linear chromosomal DNA protecting the genome from damage. In mitotic cells, telomeres can shorten with each division, unless this can be counteracted or reversed by the telomere-lengthening enzyme, telomerase (Blackburn, 1991; Wolkowitz et al., 2011), telomere length regulation in mammalian cells is complex, telomere length differs between tissues (Prowse \& Greider, 1995) or even cells (Friedrich et al., 2000). 
An increase in tissue cell proliferation results in the progressive shortening of telomeres, which triggers a DNA damage response that if repaired, restores proliferation. On the contrary, if the deterioration is irreversible, the cell keeps the cell cycle at halt and can be directed to apoptosis or cellular senescence (Meeker et al., 2004; Campisi, 2011). Telomere length depends on several factors such as the speed of degradation and the speed and time of action of telomerase in each chromosome (Cawthon et al., 2003; Jaskelioff et al., 2011). Hence, telomere length decreases differentially with time in all mitotic tissues.

The brains of patients diagnosed with AD show a significant extent of oxidative damage associated with the abnormal marked accumulation of $\beta$-amyloid and the deposition of neurofibrillary tangles (Christen, 2000); stress contributes to a significant decrease in telomerase activity and consequently causes an increase in the telomere-shortening rate (Kurz et al., 2004). Biochemical studies show TTAGGG repeats are preferred sites for iron binding and iron mediated Fenton reactions, which generate hydroxyl radicals that induce the 5' cleavage of GGG (Oikawa et al., 2001). There is a minimal shortening of less than $20 \mathrm{bp}$ per cell division in cells with high antioxidative capacity and this rate increases in cells with lower antioxidative defense. Cultivating cells under enhanced oxidative stress like mild hyperoxia (40\% normobaric oxygen) shortens the telomeres prematurely and reduces the replicative lifespan accordingly (Saretzki \& Von Zglinicki, 2002).

Telomere length has been associated with life span since it reflects the number of times a cell has divided (Boonekamp et al., 2013); during aging, 50-150bp of telomeric DNA is lost with each proliferation cycle (Hochstrasser et al., 2012). It also has been associated with disease conditions such as mental stress, obesity, smoking, type 2 diabetes mellitus, 
ischemic heart diseases, AD, and Parkinson's disease (Harley et al., 1990; Allsopp et al., 1992; Zakian, 1995; Brouilette et al., 2003).

Specifically, it has been reported that patients with AD show shorter telomeres in peripheral blood mononuclear cells, monocytes, T and B cells (Panossian et al., 2003), buccal cells, and leukocytes compared to controls (Thomas et al., 2008). Also, significant differences in leukocyte telomere length (LTL) between controls, amnestic mild cognitive impairment, and AD patients has been recently reported (Scarabino et al., 2017). However, there are no reports, to our knowledge, of how and if progression of $\mathrm{AD}$ affects telomere length. Hence, we decided to evaluate changes in telomere length and oxidative stress due to the progression of AD in a murine model. Since our model has a genetic disposition to develop $\mathrm{AD}$ we expected to see an intrinsic effect of disease progression (changes in oxidative stress) on telomere length. 


\section{Materials and methods}

\section{Ethical standards}

All procedures were performed in accordance with the current rulings in Mexican law (NOM-062-ZOO-1999) and with the approval of the local Science and Ethics Committees (R-2012-785-049).

\section{Animals}

Homozygous 3xTg-AD (3xTg-AD; B6; 129-Psen 1 < tm1Mpm> Tg (APPSwe, tauP301L) 1Lfa) male mice were used as an AD murine model, and B6129SF2/J WT male mice were used as controls since this is the genetic background originally described for the transgenic mice used. Mice were purchased from Jackson Laboratories and housed in the Bioterio de la Coordinación de Investigación en Salud. Mice were housed in a 12:12 light/dark cycle at $20-22^{\circ} \mathrm{C}$ with water and food ad libitum. All animals were genotyped. Animals of three different ages were used for this project 5, 9, and 13 months. Groups for telomere length measurement were as follows: 5mo $3 x \operatorname{TgAD} n=7,5$ mo WT n=12; 9mo 3xTgAD n=9, 9mo WT $n=12 ; 13$ mo 3xTgAD n=8, and 13 mo WT $n=12$. Groups for oxidative stress measurements were as follows: 5mo $3 \times \operatorname{TgAD} n=6,5$ mo WT $n=6$; 9mo $3 x \operatorname{TgAD} n=6$, and 9 mo WT $n=6$.

\section{Biological samples and DNA extraction}

Blood samples were obtained from the mandibular vein $(\sim 0.2 \mathrm{ml})$ and treated with an erythrocyte lysis buffer. After the last blood sample was obtained from each group of age, mice were sacrificed with an overdose of pentobarbital administered intraperitoneally. The animals were then decapitated with a guillotine, the brain was carefully removed, tissue 
from the hippocampus was dissected and homogenized with lysis buffer. DNA was extracted according to the manufacturer's instructions (Thermo Scientific DNA extraction kit, K0512). Purified DNA samples were stored at $-70^{\circ} \mathrm{C}$ until use.

\section{Telomere length assessment}

All measurements were performed on samples from 5, 9, and 13 month-old mice from both strains. We followed the qPCR (StepOnePlus Real-Time PCR System, Applied Biosystems) method published by O'Callaghan and Fenech (O'Callaghan \& Fenech, 2011), an absolute quantification method that introduced an oligomer standard. A standard curve was used to determine telomere length; the 36B4 housekeeping gene was used as an endogenous calibrator. The number of copies of telomeric repeats was determined by the standard curve of telomere standard, while the standard curve of 36B4 STD was used as control, oligomers was HPLC-purified synthetized.

The $\mathrm{Ct}$ values of each sample were extrapolated in their corresponding curves by a linear regression test. The Maxima SYBR Green/ROX qPCR Master Mix 2X (ThermoScientific, California, USA) was used. The cycling conditions for both genes were: 10 minutes at $95^{\circ} \mathrm{C}$, followed by 40 cycles of $95^{\circ} \mathrm{C}$ for 15 seconds, $60^{\circ} \mathrm{C}$ for 1 minute, followed by a melting curve. Results are expressed as absolute telomere length (aTL); Kb telomere/diploid genome and were obtained as suggested by $\mathrm{O}^{\prime} \mathrm{Callaghan}$ and Fenech (O’Callaghan \& Fenech, 2011).

\section{Oxidative Stress measurements}

All measurements were performed on samples from 5 and 9 month-old mice from both strains. No 13 month-old mice were used for these measurements. 
Reactive oxygen species (ROS)

ROS were measured by the oxidation of 2-7-dichlorofluorescein (DCFH) to the fluorescent oxidized compound 2-7- dichlorofluorescein (DCF) by the presence of hydrogen peroxide. Several reactive intermediates can oxidize DCFH, so it cannot be used to determine the presence of a specific reactive species.

To evaluate the formation of reactive oxygen species (ROS) by fluorometry, $60 \mu 1$ of homogenates of the hippocampus and whole blood cells were used. A final volume of $200 \mu$ was obtained with 1x PBS buffer, $10 \mu \mathrm{L}$ of a DCFDH-diacetate at $75 \mu \mathrm{M}$. Samples were incubated in the dark for $30 \mathrm{~min}$ at $37^{\circ} \mathrm{C}$, then centrifuged at $10,000 \mathrm{rpm}$ for $10 \mathrm{~min}$; the supernatants were read in a fluorometer at an excitation wavelength of $480 \mathrm{~nm}$ and emission of $532 \mathrm{~nm}$. Results are expressed in $\mathrm{nM}$ of DCFH in $\mathrm{mg}$ of tissue samples or $\mathrm{nM}$ of DCFH in $\mu \mathrm{L}$ of serum.

\section{Lipid peroxidation}

Lipid peroxidation was measured by the production of malondialdehyde (MDA); $120 \mu \mathrm{L}$ of the homogenate of the hippocampus or $60 \mu \mathrm{L}$ whole blood cells were mixed with $60 \mu \mathrm{L}$ of $1 \mathrm{x}$ PBS and $120 \mu \mathrm{L}$ of the TBA reagent $(0.375 \mathrm{~g}$ of TBA $+15 \mathrm{~g}$ of trichloroacetic acid + $2.54 \mathrm{ml}$ of concentrated $\mathrm{HCl})$. Samples were placed in a boiling bath $\left(94^{\circ} \mathrm{C}\right)$ for $20 \mathrm{~min}$ subsequently centrifuged at $10,500 \mathrm{rpm}$ for $15 \mathrm{~min}$. The optical density of the supernatant was determined (Biotek plate reader) at a wavelength of $532 \mathrm{~nm}$. Results are expressed as $\mu \mathrm{M}$ of $\mathrm{MDA}$ in $\mu \mathrm{L}$ of serum and $\mu \mathrm{M}$ of MDA in $\mathrm{mg}$ of tissue sample.

\section{Mitochondrial viability}


Mitochondrial viability was measured by the reduction of 3-(4,5-dimethylthiazol-2yl)bromide-2,5-diphenyltetrazole (MTT nM/ $\mu \mathrm{L}) ; 100 \mu \mathrm{L}$ of brain tissue homogenate was used, to which $10 \mu \mathrm{L}$ of an MTT solution $(5 \mathrm{mg} / \mathrm{mL})$ was added, and incubated for 30 minutes at $37{ }^{\circ} \mathrm{C}$ in the dark. After incubation, samples were centrifuged at $12,000 \mathrm{rpm}$ for $3 \mathrm{~min}$. The supernatant was removed, and $500 \mu \mathrm{L}$ of isopropanol-acid was added to the pellet where it was suspended. Samples were read at a wavelength of $560 \mathrm{~nm}$ in a plate reader. Results are expressed as $\mu \mathrm{M}$ of MTT in mg of tissue.

\section{Statistical analysis}

The data analysis was carried out in Prism 6.0e and SPSS 21 commercial software. As a first approach to explore the molecular changes in the progression of Alzheimer's disease in a murine transgenic model $(3 \mathrm{xTgAD})$, we measured absolute telomere length (aTL; kb) at 5, 9, and 13 months, in addition to reactive oxygen species (DCFH; nM/ $/ \mathrm{L}$ ), lipid peroxidation (MDA; $\mu \mathrm{M} / \mu \mathrm{L})$, and mitochondrial functionality (MTT; nM/ $\mu \mathrm{L}$ ) at 5 and 9 months. All measurements were carried out on the hippocampus homogenate and whole blood cells. Quantitative variables are presented as the arithmetic median and maximums and minimums per age group: 3, 5, and 13 months.

Scattergrams show the distributions of aTL among age groups, $\mathrm{p}$-values were calculated by Kruskal-Wallis non-parametric test, and when statistical significance between groups was obtained, we performed a post-hoc test (Dunn's test) to discriminate the specific groups with significantly different medians that differ from the others.

Differences between ROS, MDA, and MTT among age groups are represented as scattergrams. A Kruskal-Wallis (KW) non-parametric test was used to calculate p-values when statistical significance between groups was obtained, we performed a post-hoc test 
(Dunn's test) to discriminate the specific groups with significantly different medians that differ from the others; in some cases, a Mann-Whitney test was used to compare between two groups.

To determine the possible relationship and strength of the relationship between ROS, MDA, and MTT with absolute telomere length among whole blood cells or hippocampus homogenate from either $\mathrm{AD}(3 \mathrm{xTgAD})$ or $\mathrm{Wt}(\mathrm{B} 6129 \mathrm{SF} 2 / \mathrm{J})$ mice at 5 or 9 months, we performed a Spearman's rank-order correlation $\left(\mathrm{r}_{\mathrm{s}}\right)$ analysis and considered the statistical significance of the correlation according to p-values less than 0.05 .

Availability of supporting data

https://osf.io/pygce/?view_only=06b96ac7527a4385b765bf3b5036d77b

\section{Competing interests}

We declare no conflict of interest. 


\section{Results}

We measured telomere length and oxidative stress in the progression of $\mathrm{AD}$ in a murine model. Table 1 shows the mean values of telomere length, measured in whole blood cells and hippocampus at 5, 9, and 13 months, as well as ROS, lipid peroxidation, and mitochondrial viability measured at 5 and 9 months, for both transgenic and wild type strains.

\section{Telomere length}

Telomere length in whole blood cells of the transgenic strain showed significant differences between age groups $(\mathrm{KW} ; \mathrm{H}(2)=14.01, \mathrm{p}<0.001)$, the 13-month-old group was significantly different from the other two groups (Dunn's post hoc; $p=0.014, p=0.002$ ). No significant differences were found between age groups from the wild type strain (KW; $H(2)=0.70 p=0.70)$. When compared between mice strains, significant differences were found between 13-month-old transgenic and wild type mice (Dunn's post hoc; $p=0.016$ ) as can be seen in Figure 1a.

Telomere length was also measured in the hippocampus, one of the first structures affected by $\mathrm{AD}$. We observed a telomere length decreasing tendency for $\mathrm{HC}$ of transgenic mice; nevertheless, we did not find significant differences between age groups within strains $(\mathrm{KW} ; \mathrm{H}(2)=2.45 \mathrm{p}=0.31$ for transgenics and $\mathrm{KW} ; \mathrm{H}(2)=2.02 \mathrm{p}=0.37$ for wild type ) or between wild type and transgenic mice $(\mathrm{KW} ; \mathrm{H}(6)=5.58 \mathrm{p}=0.34)$ as can be seen in Figure 1b. 
Table 1.

\begin{tabular}{|c|c|c|c|c|c|c|}
\hline \multirow[b]{2}{*}{ Strain } & \multirow{3}{*}{$\begin{array}{l}\text { Age } \\
\text { months }\end{array}$} & \multirow{3}{*}{ Sample } & \multicolumn{4}{|c|}{ Mean \pm SD } \\
\hline & & & Telomere & $\begin{array}{l}\text { Reactive oxygen } \\
\text { species (ROS) }\end{array}$ & $\begin{array}{l}\text { Mitochondria } \\
\text { viability }\end{array}$ & Lipid peroxidation \\
\hline & & & $\begin{array}{c}\text { aTL } \\
\text { (Mb/diploid genome) }\end{array}$ & $\begin{array}{l}\text { DCFH } \\
(\mathrm{nM})\end{array}$ & $\begin{array}{l}\text { MTT } \\
(\mu \mathrm{M})\end{array}$ & $\begin{array}{l}\text { MDA } \\
(\mu \mathrm{M})\end{array}$ \\
\hline \multirow[t]{6}{*}{$W t$} & 5 & Hippocampus & $172.1 \pm 132.9$ & $100.8 \pm 67.6$ & $0.08 \pm 0.03$ & $0.50 \pm 0.17$ \\
\hline & & Whole blood cells & $131.3 \pm 22.7$ & $635.7 \pm 158.9$ & --------- & $0.07 \pm 0.05$ \\
\hline & 9 & Hippocampus & $78.8 \pm 28.7$ & $215.2 \pm 40.3$ & $0.03 \pm 0.01$ & $0.94 \pm 0.28$ \\
\hline & & Whole blood cells & $133.2 \pm 124.2$ & $1295.0 \pm 252.5$ & ------- & $0.09 \pm 0.06$ \\
\hline & 13 & Hippocampus & $134.0 \pm 85.6$ & --o-s--- & --------- & --o--o- \\
\hline & & Whole blood cells & $96.7 \pm 60.5$ & --------- & --------- & --------- \\
\hline \multirow[t]{6}{*}{$\mathrm{Tg}$} & 5 & Hippocampus & $106.9 \pm 64.4$ & $444.5 \pm 197.3$ & $0.10 \pm 0.01$ & $0.35 \pm 0.14$ \\
\hline & & Whole blood cells & $149.0 \pm 20.9$ & $1777.2 \pm 339.5$ & --------- & $0.10 \pm 0.04$ \\
\hline & 9 & Hippocampus & $104.8 \pm 62.3$ & $1442.3 \pm 1395.5$ & $0.03 \pm 0.01$ & $1.25 \pm 0.38$ \\
\hline & & Whole blood cells & $153.4 \pm 64.7$ & $3796.1 \pm 1061.9$ & --------- & $2.81 \pm 1.49$ \\
\hline & 13 & Hippocampus & $52.2 \pm 49.5$ & -------- & -------- & -------- \\
\hline & & Whole blood cells & $15.4 \pm 9.3$ & --------- & --------- & --------- \\
\hline
\end{tabular}

Mean \pm SD

aTL, absolute telomere length; $\mathrm{Mb}$, megabase. 

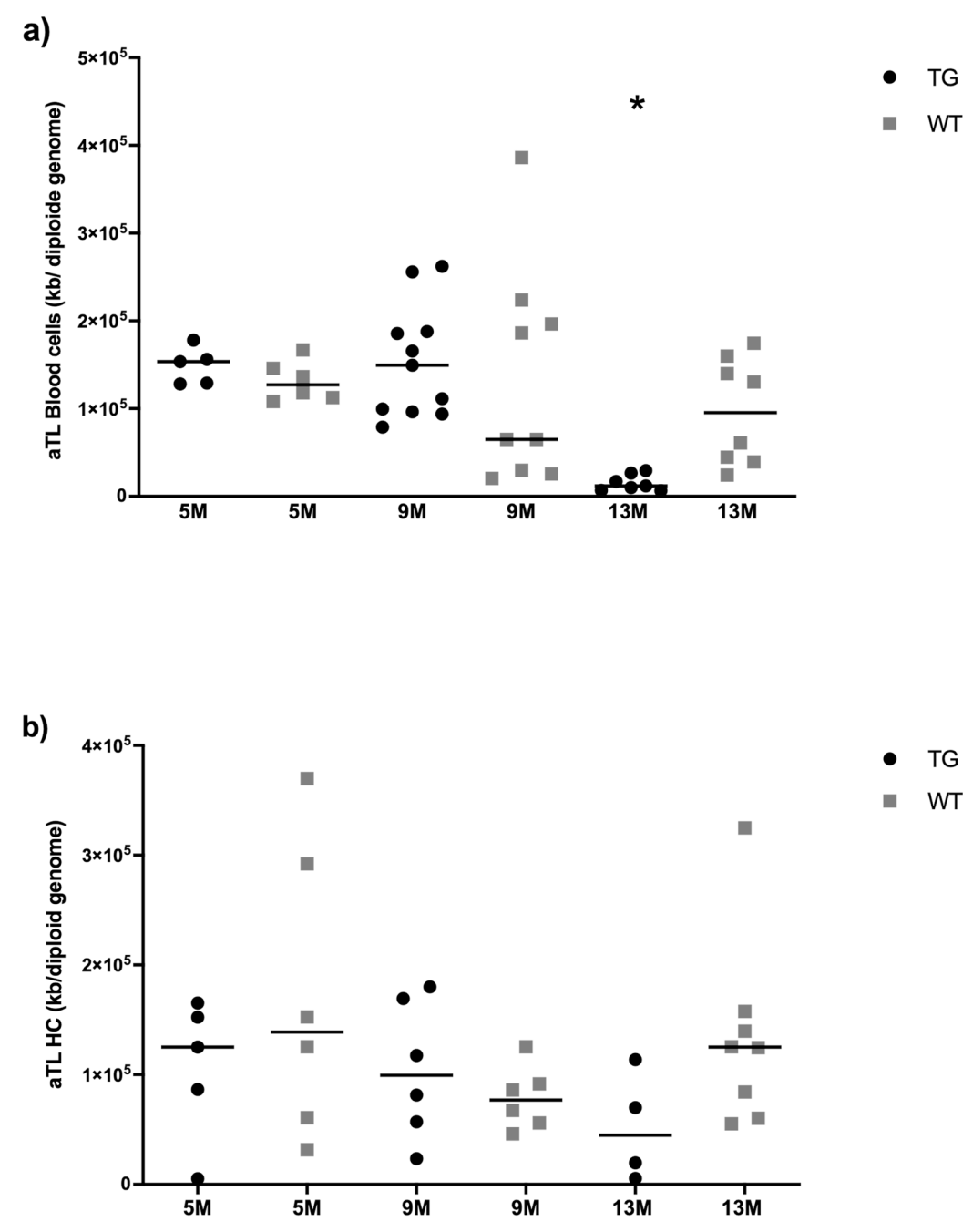

Figure 1. Absolute telomere length measured in transgenic (•black) and wild type ( $\square$ grey) mice of 5, 9 and 13 months of age. a) Blood cells telomere length decreases with age and is significant between 5 and 13 and 9 and 13 months of age in transgenic mice, but no significant changes were found for wild type. Significant differences between strains of 13 months of age were found. b) Hippocampus telomere length is not affected by strain or age group. ${ }^{*} \mathrm{p}<0.05$

\section{Oxidative stress}

In order to determine whether oxidative stress increased with the progression of $\mathrm{AD}$, we measured ROS (by DCFH) and lipid peroxidation (by MDA) at 5 and 9 months of age. 
When measured in blood cells, both ROS and lipid peroxidation showed a significant increase between age groups within strains. As shown in Figure 2a, a Kruskal wallis test show differences between groups $(\mathrm{KW} ; \mathrm{H}(3)=18.79 \mathrm{p}<0.001)$ ROS in blood cells of 9 months old transgenic mice is significantly higher than that of 5 months old mice (Dunn's post-hoc; $\mathrm{p}<0.001)$. ROS also increased between 5 and 9 months old groups of the wild type strain (Dunn's post-hoc; $p=0.002$ ). ROS increases with age in both strains, but significantly more in the transgenic mice where the 9 months group also showed differences between strains (Dunn's post-hoc; $p=0.021$ ).

Lipid peroxidation, measured by $\operatorname{MDA}(\mu \mathrm{M} / \mu \mathrm{L})$, is shown in figure $2 b$, where increases can only be seen in the 9 months-old transgenic mice group which is significantly different from every other group $(\mathrm{KW} ; \mathrm{H}(3)=10.99 \mathrm{p}=0.01)$. No other significant differences in lipid peroxidation were found. 


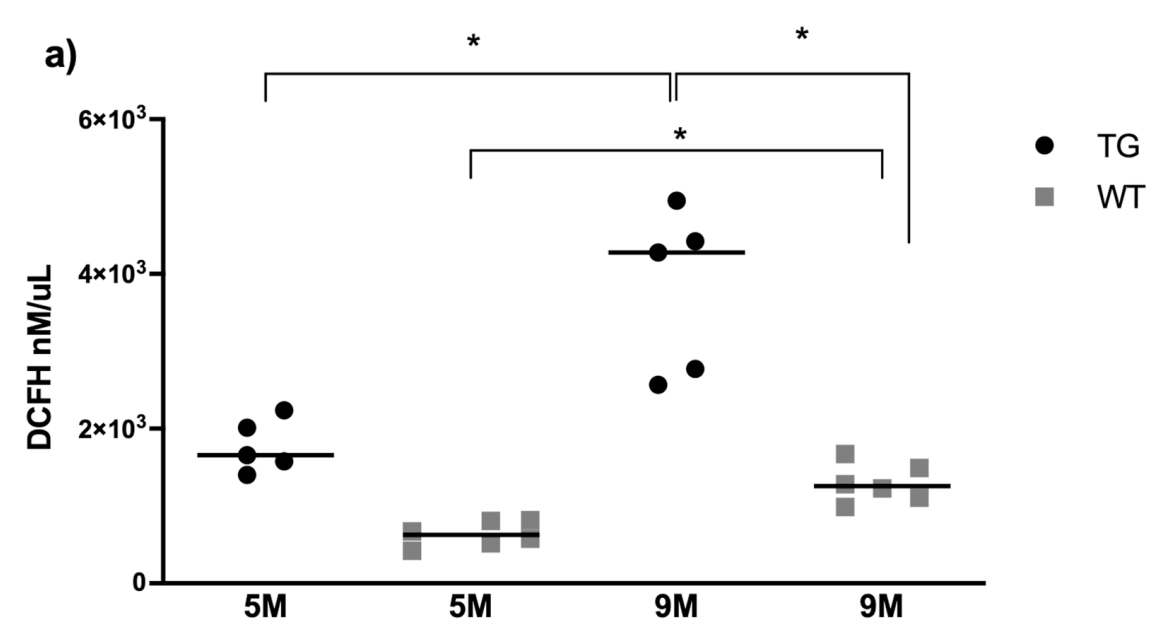

b)

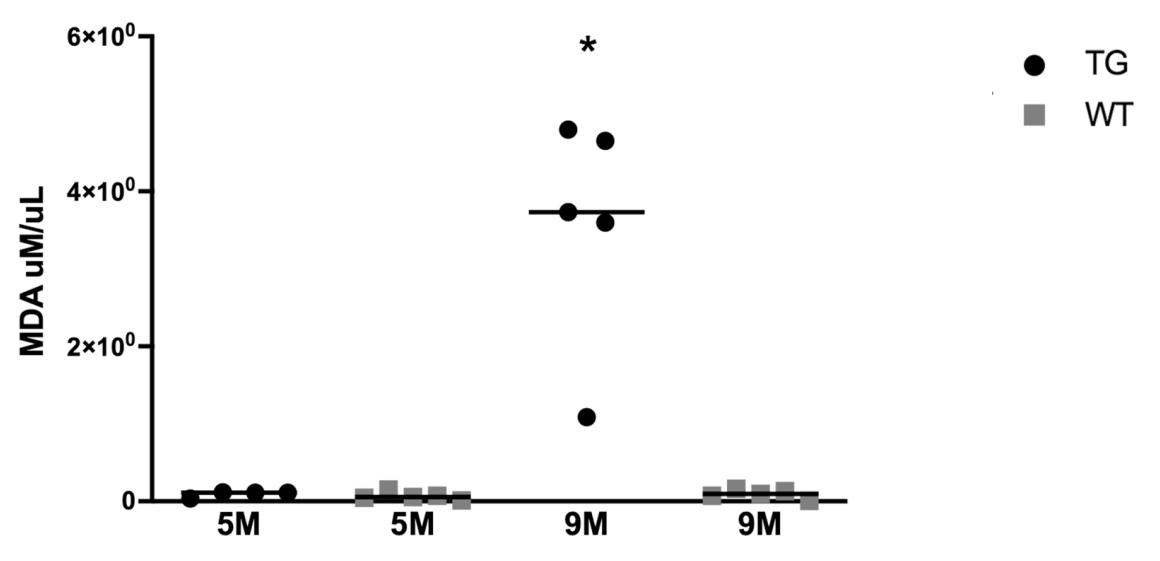

Figure 2. Oxidative stress in blood cells of transgenic ( $\bullet$ black) and wild type ( $\square$ grey) mice of 5 and 9 months of age. a) Measurement of ROS by DCFH. Blood cells ROS increases with age in both strains and is statistically significant at 9 months of age between strains. b) Lipid peroxidation measured by MDA. Significant differences were found between 9-month-old transgenic mice and every other group. * $\mathrm{p}<0.05$

When measured in the hippocampus, ROS increased with age within both strains, a Mann Whitney test showed differences between wild type $(\mathrm{Mdn}=83.30, \mathrm{Mdn}=210.3, \mathrm{U}=4 \mathrm{p}=$ 
$0.026)$ and transgenic mice in both ages $(\mathrm{Mdn}=427.5, \mathrm{Mdn}=905.3, \mathrm{U}=2 \mathrm{p}=0.032)$

moreover we could observe that increase in ROS was more in transgenic mice at 9 months than wild type mice at the same age $(\mathrm{Mdn}=905.3, \mathrm{Mdn}=210.3, \mathrm{U}=0 \mathrm{p}=0.004)$ as can be seen in Figure 3a. In lipid peroxidation significant increase between 5 and 9 months old mice for both strains, transgenic (Mann Whitney; $\mathrm{Mdn}=0.284, \mathrm{Mdn}=1.131, \mathrm{U}=0 \mathrm{p}=$ 0.008) and wild type (Mann Whitney; $\mathrm{Mdn}=0.495, \mathrm{Mdn}=0.874, \mathrm{U}=3 \mathrm{p}=0.015$ ) however no differences were observed between strains (Figure 3b). Similarly, mitochondrial viability (measured by MTT) decreased with age in both strains, transgenic mice (Mann Whitney; $\mathrm{Mdn}=0.098, \mathrm{Mdn}=0.027, \mathrm{U}=0 \mathrm{p}=0.008$ ) and wild type mice (Mann Whitney; $\mathrm{Mdn}=0.076, \mathrm{Mdn}=0.028, \mathrm{U}=0 \mathrm{p}=0.002$ ) but showed no differences between strains as shown in Figure 3c. 

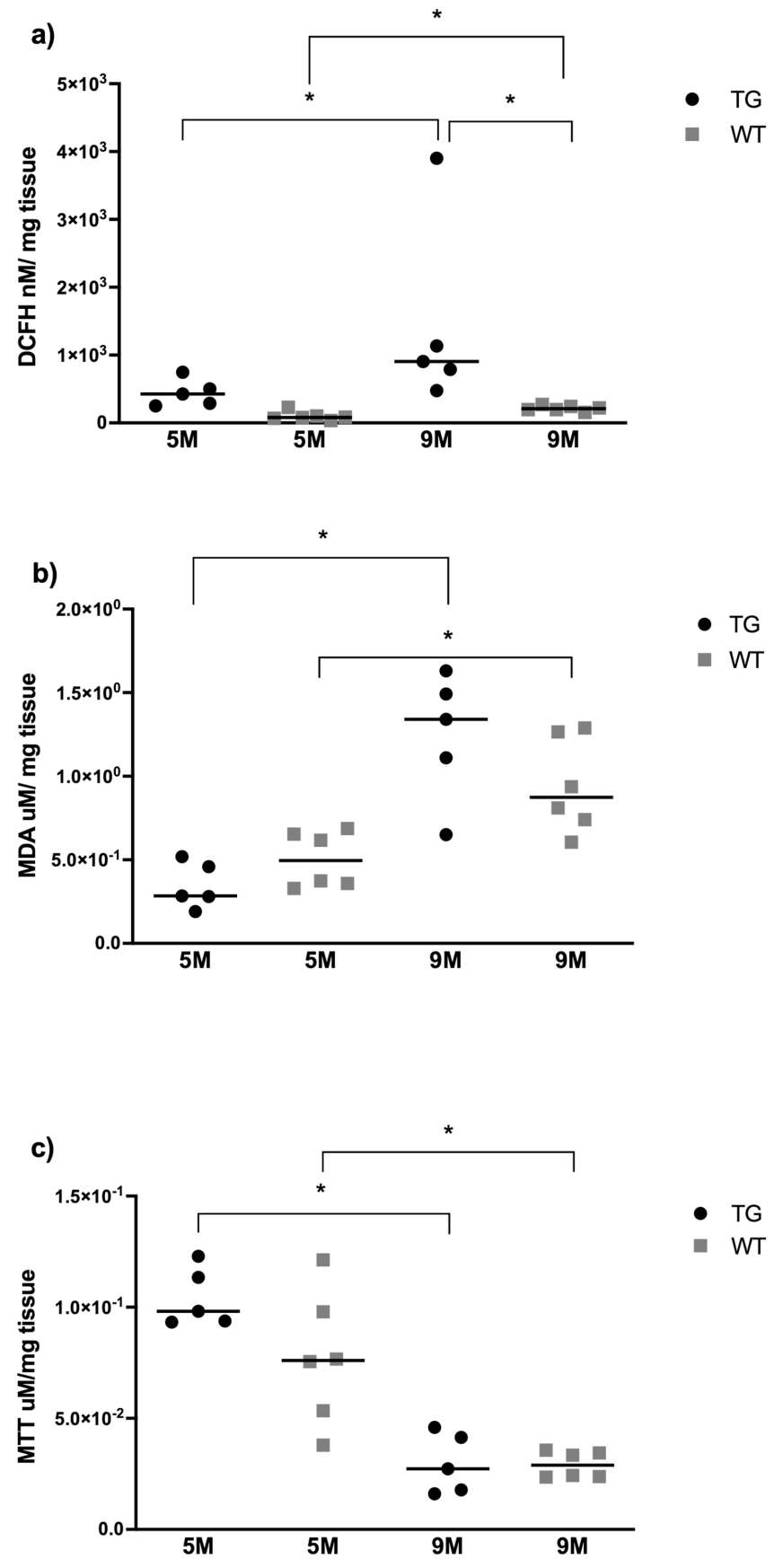

Figure 3. Oxidative stress in hippocampus homogenates of transgenic (•black) and wild type ( $\square$ grey) mice of 5 and 9 months of age. a) Measurement of ROS by DCFH. ROS increases with age in both strains and is statistically significant at 5 and 9 months of age between strains. b) Lipid peroxidation measured by MDA. Significant differences were found between 5 and 9-month groups of both strains but not between strains. c) Mitochondrial viability measured by MTT. Significant differences were found between 5 and 9-month groups of both strains but not between strains. ${ }^{*} \mathrm{p}<0.05$ 
Finally, a correlation analysis showed a low/moderate positive correlation for 5 month-old wild type mice between telomere length and ROS for the hippocampus $\left(\mathrm{HC}_{\mathrm{s}}=0.3\right)$ and whole blood cells ( $\left.\mathrm{WB}_{\mathrm{s}}=0.5\right)$ as well as for $\mathrm{MDA}\left(\mathrm{HC}_{\mathrm{s}}=0.3\right.$ and $\left.\mathrm{WB} \mathrm{r}_{\mathrm{s}}=0.7\right)$, while a low negative correlation was found for MTT in the hippocampus $\left(\mathrm{HC}_{\mathrm{s}}=-0.5\right)$. Similar correlations were seen for the 9 month-old wild type mice with the exception of a low negative correlation between $\mathrm{HC}$ telomere length and MDA $\left(\mathrm{r}_{\mathrm{s}}=-0.1\right)$ and a high positive correlation between WB telomere length and MDA $\left(\mathrm{r}_{\mathrm{s}}=0.9, \mathrm{p}=0.04\right)$ as can be seen in Figure 4.

For the transgenic strain, the hippocampus from 5 month-old mice, showed low negative correlations between telomere length and ROS, MTT, and MDA ( $\mathrm{HC}_{\mathrm{s}}=-0.2,-0.1$, and 0.3 , respectively) and high negative correlation for whole blood cells and MDA $\left(\mathrm{r}_{\mathrm{s}}=-0.8\right)$. Finally, 9 month-old mice showed moderate and high positive correlations between HC telomere length and $\operatorname{ROS}\left(r_{s}=0.9, p=0.04\right)$ and MTT $\left(r_{s}=0.7\right)$, respectively, while positive and negative moderate correlations for whole blood cells with ROS $\left(\mathrm{r}_{\mathrm{s}}=0.7\right)$ and MDA $\left(\mathrm{r}_{\mathrm{s}}=\right.$ -0.7) respectively as can be seen in Figure 4. 


\begin{tabular}{|c|c|c|c|c|c|c|c|}
\hline \multirow[b]{2}{*}{ Strain } & \multirow[b]{2}{*}{$\begin{array}{c}\text { Age } \\
\text { (Mo) }\end{array}$} & \multirow[b]{2}{*}{ Sample } & & \multicolumn{3}{|c|}{ Correlation (Rho Spearman) } & \\
\hline & & & & ROS/aTL & MDA/aTL & MTT/aTL & \\
\hline \multirow{12}{*}{ Wt } & \multirow{6}{*}{5} & \multirow{3}{*}{ Hippocampus } & $\rho$ & 0.3 & 0.3 & -0.5 & \\
\hline & & & p-value & 0.5 & 0.6 & 0.3 & $\rho$ \\
\hline & & & $\mathrm{n}$ & $6 / 6$ & $6 / 6$ & $6 / 6$ & -1 \\
\hline & & \multirow{3}{*}{$\begin{array}{l}\text { Whole blood } \\
\text { cells }\end{array}$} & $\rho$ & 0.5 & 0.7 & \multirow{3}{*}{ ND } & -0.9 \\
\hline & & & p-value & 0.3 & 0.2 & & -0.8 \\
\hline & & & $\mathrm{n}$ & $6 / 6$ & $5 / 6$ & & -0.7 \\
\hline & \multirow{6}{*}{9} & \multirow{3}{*}{ Hippocampus } & $\rho$ & 0.2 & -0.1 & -0.5 & -0.6 \\
\hline & & & p-value & 0.7 & 0.8 & 0.3 & -0.5 \\
\hline & & & $\mathrm{n}$ & $6 / 6$ & $6 / 6$ & $6 / 6$ & -0.4 \\
\hline & & \multirow{3}{*}{$\begin{array}{l}\text { Whole blood } \\
\text { cells }\end{array}$} & $\rho$ & 0.4 & 0.9 & \multirow{3}{*}{ ND } & -0.3 \\
\hline & & & p-value & 0.4 & 0.04 & & -0.2 \\
\hline & & & $\mathrm{n}$ & $6 / 9$ & $5 / 9$ & & -0.1 \\
\hline \multirow{12}{*}{$\operatorname{Tg}$} & \multirow{6}{*}{5} & \multirow{3}{*}{ Hippocampus } & $\rho$ & -0.2 & -0.3 & -0.1 & 0 \\
\hline & & & p-value & 0.7 & 0.6 & 0.9 & 0.1 \\
\hline & & & $\mathrm{n}$ & $5 / 5$ & $5 / 5$ & $5 / 5$ & 0.2 \\
\hline & & \multirow{3}{*}{$\begin{array}{l}\text { Whole blood } \\
\text { cells }\end{array}$} & $\rho$ & 0.3 & -0.8 & \multirow{3}{*}{ ND } & 0.3 \\
\hline & & & p-value & 0.6 & 0.2 & & 0.4 \\
\hline & & & $n$ & $5 / 5$ & $4 / 5$ & & 0.5 \\
\hline & \multirow{6}{*}{9} & \multirow{3}{*}{ Hippocampus } & $\rho$ & 0.9 & 0 & 0.7 & 0.6 \\
\hline & & & p-value & 0.04 & 1 & 0.2 & 0.7 \\
\hline & & & $\mathrm{n}$ & $5 / 6$ & $5 / 6$ & $5 / 6$ & 0.8 \\
\hline & & \multirow{3}{*}{$\begin{array}{l}\text { Whole blood } \\
\text { cells }\end{array}$} & $\rho$ & 0.7 & -0.7 & \multirow{3}{*}{ ND } & 0.9 \\
\hline & & & p-value & 0.2 & 0.2 & & 1 \\
\hline & & & $\mathrm{n}$ & $5 / 11$ & $5 / 11$ & & \\
\hline
\end{tabular}

Figure 4. Correlation between telomere length and oxidative stress by strain, age and tissue sample. The combined table/heatmap shows the correlation between oxidative stress (ROS, MDA, and MTT) and telomere length in the hippocampus and whole blood cells from wild-type and transgenic mice at 5 and 9 months of age in a color scale from -1 to +1 .

$\rho$, Spearman rho; aTL, absolute telomere length, Wt, wild-type; Tg, transgenic; Mo, months 


\section{Discussion}

Telomere length and oxidative stress are affected by AD progression in the $3 \mathrm{xTg}-\mathrm{AD}$ murine model. Shorter telomeres were found in blood cells of older transgenic mice compared to younger transgenic mice and same-age wild type mice. This could be a reflection of a systemic effect due to the progression of $\mathrm{AD}$ in our murine model since it is not aging but the disease itself that is causing the changes in telomere length.

On the matter, it has been reported that chronic inflammation promotes telomere attrition by increasing white blood cell replacement (Samani et al., 2001). An increase of glial fibrillary acidic protein immunoreactivity, indicative of astrogliosis, has been reported in the retinal ganglion cell layer in the late-symptomatic stages of 3xTg-AD (Edwards et al., 2014). During disease progression in the 3xTg-AD mouse model, retinal microglia showed a pro-inflammatory phenotype, with less ramified morphology, and neurodegenerative associated markers (Grimaldi et al., 2018). Hence, inflammation could promote white blood cell replacement which would reflect in telomere shortening for this murine model.

Additionally, it has been shown that elevated levels of $A \beta \quad 1-40$ and $A \beta$ 1-42 are associated with increased oxidation products in peripheral blood cells from AD patients (Coppedè \& Migliore, 2015). On the matter, plasma levels of $A \beta 1-40$ and $A \beta 1-42$ of 3xTg-AD mice have been found to increase progressively from 5 to 9 months of age (age at which this model does not yet show accumulation of $\mathrm{A} \beta$ in brain tissue), observing a significant decrease at 12 months (Cho et al., 2016).

Hence, the elevation of oxidative stress that we see with age, and that is more evident and prominent in the transgenic model, could be due to the presence of $A \beta$ in blood, which 
appears sooner than in brain tissue. However, at the time we cannot statistically prove that the elevated oxidative stress causes telomere attrition, even when it seems a likely scenario.

We found increased oxidative stress, measured by ROS and lipid peroxidation, in blood cells of older compared to younger transgenic mice; however, we found no statistical association between the increase in oxidative stress and telomere length in our model. For that purpose, $8 \mathrm{OHdG}$ may have been a better biomarker to associate with telomere length since it is directly related to DNA damage due to oxidative stress. Accordingly, a previous paper reported that $8 \mathrm{OHdG}$ is elevated in lymphocytes of $\mathrm{AD}$ patients compared to a control group (Mecocci et al., 1994). Unfortunately, this measurement was impossible to obtain at the time, and the latter study was made in humans.

Regarding our findings on telomere length in the hippocampus (HC), we only found a tendency, but no significant differences between the transgenic 13 months old mice and the younger groups. On that matter, Franco and co-workers found no changes in telomere length of the subcortical and granular areas as well as the $\mathrm{HC}$ between transgenic mice for APP and their controls. They concluded that the accumulation of amyloid-beta has no relation to telomere shortening (Franco et al., 2006). Moreover, Lukens et al. found no changes in telomere length in the cerebellum of patients with AD against controls despite a significant difference in leukocyte telomere length (Lukens et al., 2009a). However, Thomas et al., 2008 found a significant increase in telomere length in the hippocampus of brain tissue of $\mathrm{AD}$ patients compared to controls as well as a significantly shorter telomere of the younger AD compared to older AD patients (Thomas et al., 2008). Finally, Cardillo et al., 2018 found no differences in the hippocampal telomere length of 3xTg-AD 11month-old mice compared to WT controls (Cardillo et al., 2018) 
Changes in telomere length in brain tissue are tricky to interpret since most neurons do not replicate and specifically, the hippocampus shows reduced neurogenesis in AD (Dhaliwal et al., 2018). A recent stereological study in eleven-month-old 3xTg-AD mice indicated that, in spite of the occurrence of cerebral atrophy and reduced hippocampal volume, there was preservation of the total number of CA1 pyramidal neurons, suggesting a selfpreservation mechanism that may be reflected in enhanced telomere maintenance (Manaye et al., 2013; Schaeffer et al., 2017). Therefore, if shortening occurs, it is more likely to be due to environmental factors or to increased replication of glial cells (Thomas et al., 2008; Cattan et al., 2008), a distinction we did not make at the moment.

Here we found that the progression of the disease does not affect telomere length in brain tissue as it does on blood cells. On the matter, it has been reported that telomere length in skeletal muscle (a minimally replicating somatic tissue), and leukocytes (a highly proliferative hematopoietic system) shorten with age, but only leukocytes show statistically significant attrition with time (Chahine et al., 2019). Telomeres in blood cells may shorten at a greater rate than other tissues because of their high turnover rate (Nakagawa et al., 2004). Hence, inter-species, interindividual, and intertissue differences are accounted for mainly by factors such as different rates of cell replication, levels of telomerase activity, and levels of oxidative stress (Aviv, 2002).

On that matter, it is worthy to note, that here we did not take into account the effects of interstitial telomeric sequences (ITSs). The dynamics for telomere estimation are complex because telomeric repeats exist both within true telomeres at the ends of chromosomes and as ITSs in the interior of chromosomes. Quantitative PCR (Q-PCR) detects both true telomere and ITSs (Nakagawa et al., 2004; Foote et al., 2013). ITSs are likely to affect 
telomere estimates in any species that has substantial ITSs relative to true telomeres. This is problematic since it could increase the variance within a group of samples, as we can see in our measurements. Both of these effects reduce statistical power to detect significant differences in telomere length between groups (Foote et al., 2013).

Regarding aging and telomere shortening, a negative correlation between age and telomere length (Lukens et al., 2009) has been reported in human tissue and peripheral blood cells, a feature we did not find in any of our mice, wild type or transgenic. Accordingly, a comparative study in mice established no correlation between telomere length and age in these animals; the replicative aging mechanism controlling the number of cell divisions where telomere length is shortened, as has been reported in humans, appears to be different in mice (Gomes et al., 2011). Murine telomeres do not serve as a mitotic clock for replicative aging, as primary cells constitutively express telomerase, in contrast to humans, in whom telomeres play a part in replicative senescence and telomerase expression is repressed (Calado \& Dumitriu, 2013; Reichert \& Stier, 2017). Hence, the data obtained here must be taken with caution when compared to humans.

Taking it all into account, human and mice studies have both described no changes in telomere length in brain tissue samples but a shortening in telomere in whole blood cells of AD patients. Although oxidative damage can cause telomere shortening through doublestranded breaks to DNA, most telomere loss due to oxidative stress occurs during DNA replication (Calado \& Dumitriu, 2013; Reichert \& Stier, 2017). Oxidation of biomolecules in the context of AD is mainly related to neuronal membrane biomolecules and to a disruption of membrane integrity (Cheignon et al., 2018), which is in accordance to our findings of a general negative correlation found between lipid peroxidation (measured by 
MDA) and telomere length for both brain tissue and whole blood cells of transgenic mice.

This correlation is mainly evident and statistically significant for whole blood cells of transgenic 5 month-old mice.

Our results show that telomere attrition is due to the progression of the disease, supporting the newest discovery of $\mathrm{AD}$ being a disease that does not only affect the central nervous system but has a systemic effect.

Aging, as well as AD, has an effect on oxidative stress (Panossian, 2003; de Souza-Pinto et $a l ., 2008)$ which we were able to confirm here. Both mice strains had increased markers of oxidative stress for blood and tissue samples when compared to a younger group, but transgenic mice showed even higher values suggesting an additive effect of age and Alzheimer's Disease. However, no statistical correlation between oxidative stress increase and telomere length was found. Independently of age, our results point to a distinct, not ROS-related, and yet to be determined, the global mechanism by which the Alzheimer phenotype promotes cell proliferation and consequently telomere shortening.

\section{Conclusion}

Higher oxidative stress and shorter telomere length in peripheral blood were observed with the progression of the disease but no statistical correlation between them was found. No changes in telomere length but an increase in oxidative stress was found in the hippocampus of both strains. The presence of changes in peripheral blood cells of this mouse model suggests that AD affects the individual systemically due to its progression. 


\section{Acknowledgments}

This work was supported by the Fondo Sectorial de Investigación para la Educación del

Consejo Nacional de Ciencia y Tecnología (CONACyT) with the project number

CONACYT 179594.

We would like to thank Ariadna Galvan Flores for her help with the design and elaboration of the graphical abstract and figures.

This study was performed in partial fulfilment of the requirements for the degree of KMG (MSc) and $\mathrm{AIH}(\mathrm{PhD})$ who thank the Posgrado en Ciencias Biológicas, Biología

Experimental, and acknowledge the scholarships provided by CONACYT (294248 and 298982 respectively) and KMG for IMSS (99096757). 


\section{Abbreviations}

A $\beta$ - amyloid beta

aTL- absolute telomere length

AD- Alzheimer's disease

DNA- deoxyribonucleic acid

DCFH- 2-7-dichlorofluorescein

DCF- oxidized compound of DCFH

HC- hippocampus

ITSs- interstitial telomeric sequences

MDA- malondialdehyde

mo- months

MTT- 3-(4,5-dimethylthiazol-2-yl)bromide-2,5-diphenyltetrazole

qPCR- quantitative polymerase chain reaction

ROS- reactive oxygen species 


\section{References}

Allsopp, R.C., Vaziri, H., Patterson, C., Goldstein, S., Younglai, E.V., Futcher, A.B., Greider, C.W., \& Harley, C.B. (1992) Telomere length predicts replicative capacity of human fibroblasts. Proc. Natl. Acad. Sci. USA, 89, 10114-10118.

Aviv, A. (2002) Telomeres, sex, reactive oxygen species, and human cardiovascular aging. J. Mol. Med., 80, 689-695.

Blackburn, E.H. (1991) Structure and function of telomeres. Nature, 350, 569-573.

Boonekamp, J.J., Simons, M.J.P., Hemerik, L., \& Verhulst, S. (2013) Telomere length behaves as biomarker of somatic redundancy rather than biological age. Aging Cell, 12, 330-332.

Brouilette, S., Singh, R.K., Thompson, J.R., Goodall, A.H., \& Samani, N.J. (2003) White cell telomere length and risk of premature myocardial infarction. Arterioscler. Thromb. Vasc. Biol., 23, 842-846.

Butterfield, D.A. \& Sultana, R. (2011) Methionine-35 of a $\beta(1-42)$ : importance for oxidative stress in Alzheimer disease. J. Amino Acids, 2011, 198430.

Calado, R.T. \& Dumitriu, B. (2013) Telomere dynamics in mice and humans. Semin.

Hematol., 50, 165-174.

Campisi, J. (2011) Cellular senescence: putting the paradoxes in perspective. Curr.

Opin. Genet. Dev., 21, 107-112.

Cardillo, G. de M., de Mattos Cardillo, G., de Jesus Rodrigues De-Paula, V., Ikenaga, E.H., Costa, L.R., Catanozi, S., Schaeffer, E.L., Gattaz, W.F., Kerr, D.S., \& Forlenza, O.V. (2018) Chronic Lithium Treatment Increases Telomere Length in Parietal Cortex and Hippocampus of Triple-Transgenic Alzheimer's Disease Mice. J.Alzheimers Dis., 63, 93-101.

Cattan, V., Mercier, N., Gardner, J.P., Regnault, V., Labat, C., Mäki-Jouppila, J., Nzietchueng, R., Benetos, A., Kimura, M., Aviv, A., \& Lacolley, P. (2008) Chronic oxidative stress induces a tissue-specific reduction in telomere length in CAST/Ei mice. Free Radic. Biol. Med., 44, 1592-1598.

Cawthon, R.M., Smith, K.R., O’Brien, E., Sivatchenko, A., \& Kerber, R.A. (2003)

Association between telomere length in blood and mortality in people aged 60 years or older. Lancet, 361, 393-395.

Chahine, M.N., Toupance, S., El-Hakim, S., Labat, C., Gautier, S., Moussallem, T., Yared, P., Asmar, R., \& Benetos, A. (2019) Telomere length and age-dependent telomere attrition: the blood-and-muscle model. Can. J. Physiol.Pharm., 97, 328-334. Cheignon, C., Tomas, M., Bonnefont-Rousselot, D., Faller, P., Hureau, C., \& Collin, F. (2018) Oxidative stress and the amyloid beta peptide in Alzheimer's disease. Redox Biol., 14, 450-464.

Cho, S.M., Lee, S., Yang, S.-H., Kim, H.Y., Lee, M.J., Kim, H.V., Kim, J., Baek, S., Yun, J., Kim, D., Kim, Y.K., Cho, Y., Woo, J., Kim, T.S., \& Kim, Y. (2016) Age- 
dependent inverse correlations in CSF and plasma amyloid- $\beta(1-42)$ concentrations prior to amyloid plaque deposition in the brain of 3xTg-AD mice. Sci. Rep., 6, 20185. Christen, Y. (2000) Oxidative stress and Alzheimer disease. Am. J. Clin. Nutr., 71, $621 \mathrm{~S}-629 \mathrm{~S}$.

Coppedè, F. \& Migliore, L. (2015) DNA damage in neurodegenerative diseases. Mutat. Res., 776, 84-97.

Czech, C., Tremp, G., \& Pradier, L. (2000) Presenilins and Alzheimer's disease: biological functions and pathogenic mechanisms. Prog. Neurobiol., 60, 363-384. de Souza-Pinto, N.C., Wilson, D.M., 3rd, Stevnsner, T.V., \& Bohr, V.A. (2008) Mitochondrial DNA, base excision repair and neurodegeneration. DNA Repair , 7, 1098-1109.

Dhaliwal, J., Kannangara, T.S., Vaculik, M., Xue, Y., Kumar, K.L., Maione, A., Béïque, J.-C., Shen, J., \& Lagace, D.C. (2018) Adult hippocampal neurogenesis occurs in the absence of Presenilin 1 and Presenilin 2. Sci. Rep., 8, 17931.

Ding, Y., Zhao, J., Zhang, X., Wang, S., Viola, K.L., Chow, F.E., Zhang, Y., Lippa, C., Klein, W.L., \& Gong, Y. (2019) Amyloid Beta Oligomers Target to Extracellular and Intracellular Neuronal Synaptic Proteins in Alzheimer's Disease. Front. Neurol., 10, 1140.

Edwards, M.M., Rodríguez, J.J., Gutierrez-Lanza, R., Yates, J., Verkhratsky, A., \& Lutty, G.A. (2014) Retinal macroglia changes in a triple transgenic mouse model of Alzheimer's disease. Exp. Eye Res., 127, 252-260.

Foote, C.G., Vleck, D., \& Vleck, C.M. (2013) Extent and variability of interstitial telomeric sequences and their effects on estimates of telomere length. Mol. Ecol. Resour., 13, 417-428.

Franco, S., Blasco, M.A., Siedlak, S.L., Harris, P.L.R., Moreira, P.I., Perry, G., \& Smith, M.A. (2006) Telomeres and telomerase in Alzheimer's disease: epiphenomena or a new focus for therapeutic strategy? Alzheimers. Dement., 2, 164-168.

Friedrich, U., Griese, E., Schwab, M., Fritz, P., Thon, K., \& Klotz, U. (2000)

Telomere length in different tissues of elderly patients. Mech. Ageing Dev., 119, 8999.

Gomes, N.M.V., Ryder, O.A., Houck, M.L., Charter, S.J., Walker, W., Forsyth, N.R., Austad, S.N., Venditti, C., Pagel, M., Shay, J.W., \& Wright, W.E. (2011) Comparative biology of mammalian telomeres: hypotheses on ancestral states and the roles of telomeres in longevity determination. Aging Cell, 10, 761-768.

Grimaldi, A., Brighi, C., Peruzzi, G., Ragozzino, D., Bonanni, V., Limatola, C., Ruocco, G., \& Di Angelantonio, S. (2018) Inflammation, neurodegeneration and protein aggregation in the retina as ocular biomarkers for Alzheimer's disease in the 3xTg-AD mouse model. Cell Death Dis., 9, 685.

Harley, C.B., Futcher, A.B., \& Greider, C.W. (1990) Telomeres shorten during ageing of human fibroblasts. Nature, 345, 458-460.

Hochstrasser, T., Marksteiner, J., \& Humpel, C. (2012) Telomere length is age- 
dependent and reduced in monocytes of Alzheimer patients. Exp. Gerontol., 47, 160163.

Jaskelioff, M., Muller, F.L., Paik, J.-H., Thomas, E., Jiang, S., Adams, A.C., Sahin, E., Kost-Alimova, M., Protopopov, A., Cadiñanos, J., Horner, J.W., Maratos-Flier, E., \& Depinho, R.A. (2011) Telomerase reactivation reverses tissue degeneration in aged telomerase-deficient mice. Nature, 469, 102-106.

Kurz, D.J., Decary, S., Hong, Y., Trivier, E., Akhmedov, A., \& Erusalimsky, J.D. (2004) Chronic oxidative stress compromises telomere integrity and accelerates the onset of senescence in human endothelial cells. J. Cell Sci., 117, 2417-2426.

Lukens, J.N., Van Deerlin, V., Clark, C.M., Xie, S.X., \& Johnson, F.B. (2009)

Comparisons of telomere lengths in peripheral blood and cerebellum in Alzheimer's disease. Alzheimers. Dement., 5, 463-469.

Manaye, K.F., Mouton, P.R., Xu, G., Drew, A., Lei, D.-L., Sharma, Y., William Rebeck, G., \& Turner, S. (2013) Age-related loss of noradrenergic neurons in the brains of triple transgenic mice. Age, 35, 139-147.

Mecocci, P., MacGarvey, U., \& Flint Beal, M. (1994) Oxidative damage to mitochondrial DNA is increased in Alzheimer's disease. Ann. Neurol., 36, 747-751. Meeker, A.K., Hicks, J.L., Iacobuzio-Donahue, C.A., Montgomery, E.A., Westra, W.H., Chan, T.Y., Ronnett, B.M., \& De Marzo, A.M. (2004) Telomere length abnormalities occur early in the initiation of epithelial carcinogenesis. Clin. Cancer Res., 10, 3317-3326.

Meyer-Luehmann, M., Coomaraswamy, J., Bolmont, T., Kaeser, S., Schaefer, C., Kilger, E., Neuenschwander, A., Abramowski, D., Frey, P., Jaton, A.L., Vigouret, J.M., Paganetti, P., Walsh, D.M., Mathews, P.M., Ghiso, J., Staufenbiel, M., Walker, L.C., \& Jucker, M. (2006) Exogenous induction of cerebral beta-amyloidogenesis is governed by agent and host. Science, 313, 1781-1784.

Nakagawa, S., Gemmell, N.J., \& Burke, T. (2004) Measuring vertebrate telomeres: applications and limitations. Mol. Ecol., 13, 2523-2533.

O'Callaghan, N.J. \& Fenech, M. (2011) A quantitative PCR method for measuring absolute telomere length. Biol. Proced. Online, 13, 3.

Oddo, S., Caccamo, A., Shepherd, J.D., Murphy, M.P., Golde, T.E., Kayed, R., Metherate, R., Mattson, M.P., Akbari, Y., \& LaFerla, F.M. (2003) Triple-transgenic model of Alzheimer's disease with plaques and tangles: intracellular Abeta and synaptic dysfunction. Neuron, 39, 409-421.

Oikawa, S., Tada-Oikawa, S., \& Kawanishi, S. (2001) Site-specific DNA damage at the GGG sequence by UVA involves acceleration of telomere shortening.

Biochemistry, 40, 4763-4768.

Panossian, L. (2003) Telomere shortening in T cells correlates with Alzheimer's disease status. Neurobiol. Aging, 24, 77-84.

Panossian, L.A., Porter, V.R., Valenzuela, H.F., Zhu, X., Reback, E., Masterman, D., Cummings, J.L., \& Effros, R.B. (2003) Telomere shortening in T cells correlates with 
Alzheimer's disease status. Neurobiol. Aging, 24, 77-84.

Prowse, K.R. \& Greider, C.W. (1995) Developmental and tissue-specific regulation of mouse telomerase and telomere length. Proc. Natl. Acad. Sci. U. S. A., 92, 4818-4822. Reichert, S. \& Stier, A. (2017) Does oxidative stress shorten telomeres? A review. Biol. Lett., 13, 20170463.

Samani, N.J., Boultby, R., Butler, R., Thompson, J.R., \& Goodall, A.H. (2001)

Telomere shortening in atherosclerosis. Lancet, 358, 472-473.

Saretzki, G. \& Von Zglinicki, T. (2002) Replicative Aging, Telomeres, and Oxidative Stress. Ann. N Y Acad. Scie., 959, 24-29.

Scarabino, D., Broggio, E., Gambina, G., \& Corbo, R.M. (2017) Leukocyte telomere length in mild cognitive impairment and Alzheimer's disease patients. Exp. Gerontol., 98, 143-147.

Schaeffer, E.L., Catanozi, S., West, M.J., \& Gattaz, W.F. (2017) Stereological investigation of the CA1 pyramidal cell layer in untreated and lithium-treated $3 \times \mathrm{Tg}$ AD and wild-type mice. Ann. Anat., 209, 51-60.

Thomas, P., O’ Callaghan, N.J., \& Fenech, M. (2008) Telomere length in white blood cells, buccal cells and brain tissue and its variation with ageing and Alzheimer's disease. Mech. Ageing Dev., 129, 183-190.

Wolkowitz, O.M., Mellon, S.H., Epel, E.S., Lin, J., Dhabhar, F.S., Su, Y., Reus, V.I., Rosser, R., Burke, H.M., Kupferman, E., Compagnone, M., Nelson, J.C., \& Blackburn, E.H. (2011) Leukocyte telomere length in major depression: correlations with chronicity, inflammation and oxidative stress--preliminary findings. PLoS One, $\mathbf{6}$, e17837.

Zakian, V.A. (1995) Telomeres: beginning to understand the end. Science, 270, 16011607. 